\title{
Neosabellaria vitiensis, n. sp. (Annelida: Polychaeta: Sabellariidae), from Shallow Water of Suva Harbor, Fiji ${ }^{1}$
}

\author{
Fulie H. Bailey-Brock, ${ }^{2}$ D. W. Kirtley, ${ }^{3}$ Eijirob Nishi, ${ }^{4}$ and Susanne M. 7. Pobler ${ }^{5}$
}

\begin{abstract}
A new species of the genus Neosabellaria Kirtley, 1994, is described from shallow-water locations of Suva Harbor, Fiji. Neosabellaria vitiensis BaileyBrock, Kirtley, Nishi, \& Pohler, n. sp., is a gregarious sabellariid; its tubes are constructed of sand and shell debris and form small "reefs" exposed during low tides. The new species is distinguished by the structure of opercular paleae in the middle row, which are shoe-shaped with circular tips, and paleae in the outer row, which have distal lateral teeth and denticulate median plume. Detailed morphological features of the new species are described and compared with other Pacific sabellariid species, particularly with most closely related $N$. clandestina (Menon \& Sareen, 1966). Neosabellaria vitiensis is endemic to the Fiji Islands.
\end{abstract}

Sabellariid polychaetes are well known as reef builders in shallow waters throughout temperate to tropical oceans (Kirtley 1992, 1994, Pandolfi et al. 1998). In the Pacific, Bailey-Brock (1985:202-203, fig. 5) reported that an unidentified species of Sabellaria from Viti Levu, Fiji, inhabited tubes of fine sand grains cemented together in a honeycomb structure that encrusts boulders in Suva Harbor. She and the late David W. Kirtley subsequently studied the specimens and concluded that they belonged to a new species, but the generic designation was not clear at that time. Recently, Pohler (2004) reported the ecology of sabellariids forming

${ }^{1}$ The work by E.N. was partly funded by Kanagawa Academy of Science and Technology (KAST) and Kurita Water Research Foundation. Manuscript accepted 21 September 2006.

${ }^{2}$ Corresponding author: Department of Zoology, University of Hawai'i at Mānoa, Honolulu, Hawai'i (phone: 808-956-6149; fax: 808-956-9812; e-mail: jbrock@hawaii.edu).

${ }^{3}$ Deceased in 1997.

${ }^{4}$ Manazuru Marine Laboratory, Yokohama National University, Manazuru, Kanagawa, 259-0202, Japan (e-mail: enishi@ynu.ac.jp).

${ }^{5}$ Marine Studies Programme, University of the South Pacific, Suva, Fiji Islands (e-mail: pohler_s@usp.ac.fj).

Pacific Science (2007), vol. 61, no. 3:399-406

(C) 2007 by University of Hawai'i Press

All rights reserved large aggregations in the same locality in Laucala Bay. The former collection examined earlier by the late D.K. and J.B.-B. and the latter specimens belong to the same species, and thus we describe it here as a new species in Neosabellaria Kirtley, 1994. Both Sabellaria and Neosabellaria were placed in the subfamily Sabellariinae on the basis of having three parathoracic segments. The two genera were initially separated by the complete fusion of opercular crown and opercular stalk along the entire anterior margin in Neosabellaria Kirtley, 1994; and by the anterior end of the opercular stalk completely divided at the anterior midline into symmetrical halves in $\mathrm{Sa}$ bellaria Lamarck, 1812. Other morphological features that differ between the two genera include the structure of the middle paleae, shapes of paleal tips, and presence or absence of nuchal spines (see in Kirtley [1994]).

\section{MATERIALS AND METHODS}

On 22 June 1980 worms were collected (by R. E. Brock) from the intertidal to subtidal region adjacent to Suva Harbor. On 15 June 2004 worms were collected (by S. Pohler), from nearshore areas between the University of the South Pacific (USP) Marine Campus (MSP) and Umaria Park (Q.E.D. Park) and on the tidal flats between the MSP Jetty and the Suva Bowling Club, Fiji (Pohler 2004). The intertidal flat is located within Laucala 
Bay $\left(18.09^{\circ} \mathrm{S}, 178.27^{\circ} \mathrm{E}\right)$ and Suva Harbor and is protected by the Suva barrier reefs. There are river outlets and point drainage sources within the study area that could affect salinity concentration along this intertidal flat (Bailey-Brock 1985).

The colonies (Figure 1A-D) were collected by hand in 1980 and 2004. Worms in tubes were fixed in $10 \%$ formalin in seawater. Some tubes were broken and approximately 50 worms removed. Another approximately 20 specimens were fixed inside their tubes to preserve tube morphology. All specimens were preserved in $70-75 \%$ ethanol.

The external morphology was examined using a stereomicroscope. Detailed observation of chaetae and paleae was done later on dissected specimens; these structures were mounted in glycerol on glass slides and examined with a phase-contrast compound microscope.

The following abbreviations are used in the text: AHF LACM POLY, Allan Hancock Foundation Polychaete Collection, Natural History Museum of Los Angeles County, Los Angeles, California; AM, Australian Museum, Sydney, Australia; Asızw, Natural History Museum, Research Center for Biodiversity, Academia Sinica, Taipei, Taiwan Republic; врвм, Bernice P. Bishop Museum, Honolulu, Hawai'i; свм, Natural History Museum and Institute, Chiba, Japan; смNH, Coastal Branch of Natural History Museum and Institute, Chiba, Japan; Ecosur, Departamento Ecología Acutica, ECOSUR, Chetumal, Mexico; кмNн, Kitakyushu Museum of Natural History and Human History, Kitakyushu, Fukuoka, Japan; мвм, Marine Biological Museum, Institute of Oceanology, Chinese Academy of Sciences, Qingdao, Peoples Republic of China; Mncnm, Museo Nacional de Ciencias Naturales de Madrid, Spain; MN/RJ, National Museum of Federal University of Rio de Janeiro, Brazil; MSP/UsP, Marine Studies Programme, University of the South Pacific, Fiji; mv, Museum of Victoria, Melbourne, Australia; NHм, The Natural History Museum, London, U.K.; NTM, Museum and Art Gallery of the Northern Territory, Australia; Rвсм, Royal British Columbia Museum, Canada; Rмвc, Raffles Museum
Biodiversity Center, Singapore; sama, South Australian Museum, Adelaide, Australia; SMF, Senckenberg Museum, Frankfurt, Germany; smrc, Shimoda Marine Research Center, Tsukuba University, Japan; UsNm, Smithsonian Institution, National Museum of Natural History, Washington, D.C.; ziHu, Zoological Institute, Hokkaido University, Hokkaido, Japan; zмв, Museum für naturkunde der Humboldt-Universität zu Berlin, Germany; zMH, Zoological Museum of Hamburg, Germany; zmuc, Zoological Museum, University of Copenhagen, Denmark.

RESULTS

Family Sabellariidae Johnston, 1865

Genus Neosabellaria Kirtley, 1994

Neosabellaria vitiensis Bailey-Brock, Kirtley, Nishi \& Pohler, n. sp.

Figures 1-4

type material. Holotype: B. P. Bishop Museum, врвм R2892, Suva, Fiji; mangrove area, intertidal, 15 June 2004, S. Pohler. Paratypes: In total over 30 worms are designated as paratypes including 1 small colony (CMNHZW01661) of more than 20 worms and tube structures. Collection data for the following are the same as for the holotype: AHF LACM POLY-2179; AM W.31026; ASIZW000689; свм-ZW 976; смNн-ZW 01659-01664; ECOSUR-00067; KMNHIvR700,133-700,134; MBм 119722; MNCN 16.01/10828; MN/RJP-341; MV F109482; NHM 2006.1281-2; NTM W20107; ввсм-6-61-1-6-61-2; вмвс ZRC 2006.0124; SAMA E 3604; SMF 16580; SMRC POL 003; USNM 1092281; ZIHU-3197, 3198; zмв Vermes 11221; zмн P-24731; zмUCPOL-1838. Collection data for врвм R2131 and USNM 97447-8: intertidal to subtidal region adjacent to Suva Harbor, Fiji, 22 June 1980, collected by R. E. Brock.

other material examined. Neosabellaria uschakovi Kirtley, 1994: UsNm 38577, 2 paratype specimens, Tartar Strait, 7-8 m, St.20/2206, collected by Okriamkin, 1931, Russia.

Neosabellaria cementarium (Moore, 1906): Nakanose, Akkeshi, Hokkaido, by dredge, collected by T. Kato, смNH-ZW00873, 

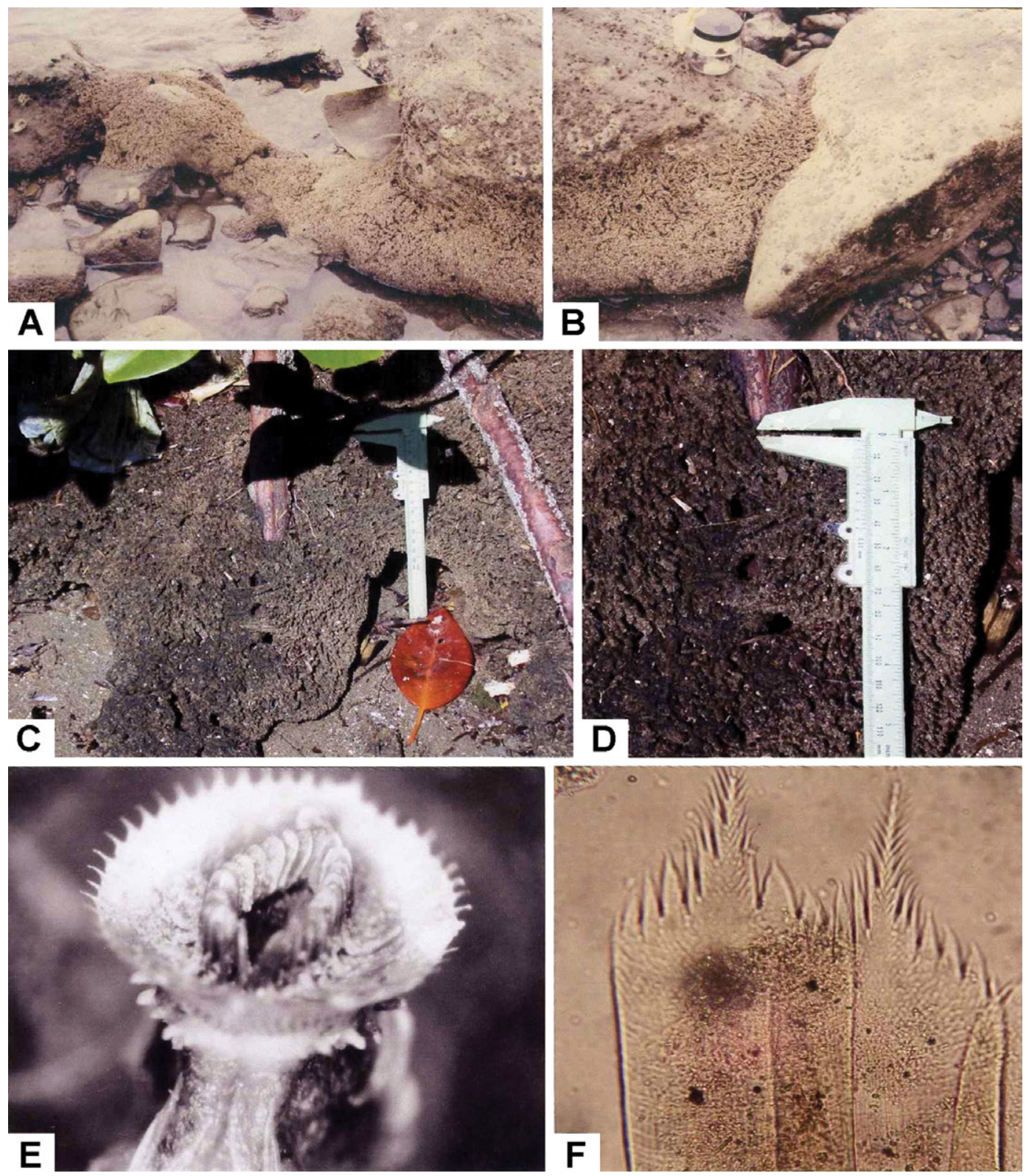

Figure 1. Neosabellaria vitiensis, n. sp., reef and colonies $(A-D)$ and head region, crown $(E)$ and outer paleae $(F)$. $A-B$, worm colony on rock, Suva Harbor (photographs by R. Brock); $C-D$, worm colony on mangrove root, Suva Harbor (photographs by S. Pohler); $E$, crown, dorsal view; $F$, outer paleae, microscopic view (cmNH-ZW01662).

00874, 1 July 1995; (same site and by same collector): -ZW01202, 5 July 1994; -ZW01204, 15 April 1998; -ZW01205, 21 June 2001 (cited by Nishi and Kato 2002).
DESCRIPTION. Holotype: mature female, complete, $7.0 \mathrm{~mm}$ long, $0.8-1.0 \mathrm{~mm}$ wide at widest part of opercular crown, $1.0 \mathrm{~mm}$ wide at parathoracic chaetigers. Paratypes: 5.0- 
$15.0 \mathrm{~mm}$ long, $0.8-1.2 \mathrm{~mm}$ wide at parathoracic chaetigers. Body of worm creamy or shiny white. Anterior end of opercular stalk fused into a lobe (Figures $2 A, B, 3 A-C$ ). Lobe narrowing anteriorly, sloping posteriorly toward dorsal midline (Figure 3B). Operculum flat to slightly concave or dish-shaped (Figures $1 E, 2 B$ ). Color of crown tan to brown or charcoal black in specks and blotches. Feeding tentacles pale or with brown pigments. Opercular paleae in three concentric rows (Figures $1 E, 2 B$ ). Feeding tentacles extend beyond length of operculum in some worms, shorter and not obscuring operculum in others. Paleae bright yellow or light brown.

Outer row with 16-24 flattened, rectangular paleae on each side (Figures $1 E, 2 B, 3 B$ ). Outer paleae (op) approximately $0.3 \mathrm{~mm}$ long (excluding median plume) and $0.1 \mathrm{~mm}$ wide, curved slightly outward from longitudinal axis of shaft. Inner surface of blade with approximately 40 to 50 fine, closely spaced thecal bands (Figure 4A). Distal ends of outer paleae with single median plume and 3 to up to 9 pairs of distal lateral teeth with sharp tips, sometimes bent at tip $(n=30$ from two paratypes [CMNH-ZW01662 and 01663], mean 5.87, $\mathrm{SD}=1.36$ ) (Figures $1 E$, $4 A, B, C)$. Median plume extended, approximately $0.01-0.015 \mathrm{~mm}$ long, denticulate with 7-15 small lateral teeth on each side $(n=30$ from two paratypes [смNH-ZW01662 and 01663], mean 1.2, $\mathrm{SD}=2.60)$, decreasing in size distally (Figure $4 B, C$ ). Distal lateral and lateral teeth of plume occasionally continuous and difficult to separate from each other; in total 12-20 for both distal lateral and lateral teeth of plume (Figures $1 F, 4 A, B, C$ ).

Middle paleae of one form, 8 to 14 pairs in each side, shoe shaped, with rounded tip, blade with thecal bands (Figures 2B, 4D,E). Inner paleae with 5-12 pairs, smaller or similar in size to middle paleae, with shorter blades (Figure 4F). Surface of excavated blade with thecal bands. Nuchal spines absent.

Anterior outer margin of opercular crown with 8-12 fleshy conical papillae (cp) in single row on each side (Figure $3 A, B$ ). Ventral margin of buccal cavity with over 20 longitudinal rows of feeding tentacles $(\mathrm{ft})$ on each side

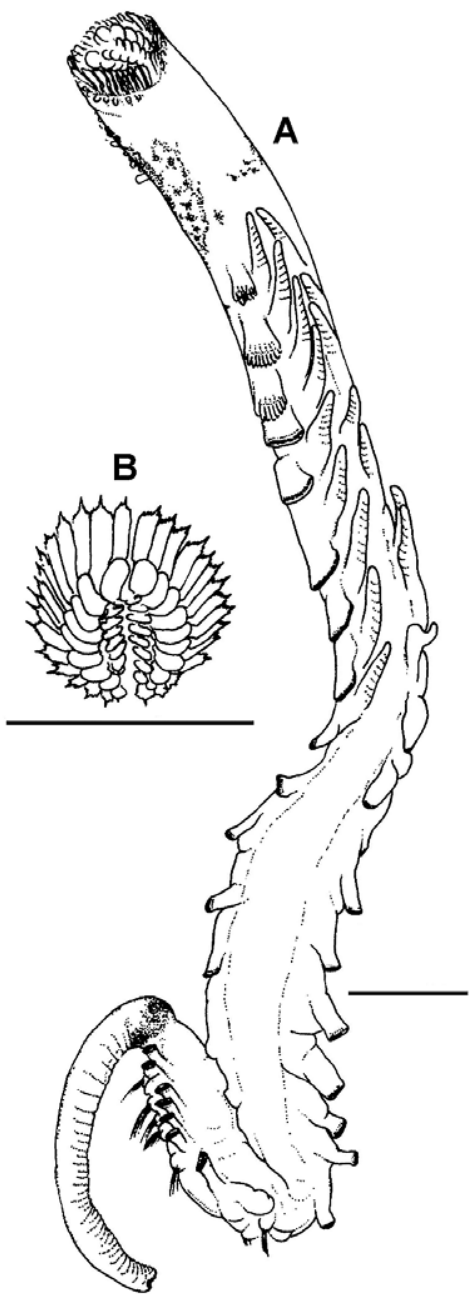

Figure 2. Neosabellaria vitiensis, n. sp., whole view ( $A$, paratype, врвм R2131) and crown view ( $B$, paratype, сMNH-ZW01664). Scale $=1.0 \mathrm{~mm}$.

(Figures $1 E, 3 B, C$ ). Building organ (bo) Ushaped, with conical cirri, forming upper lip on ventral side (Figure $3 C$ ).

Inferior lobes of second chaetiger with fascicle of 5-7 bipinnate, capillary chaetae and conical lateral cirrus (Figure $3 A, B$ ). Superior lobes with achaetous conical cirri along lateral margin of opercular lobe, with dorsal conical branchiae (br) (Figure 3A,B).

Three parathoracic chaetigers (ps) with 6-10 stout, oar-shaped chaetae and spinelike companion chaetae in two or three rows on 


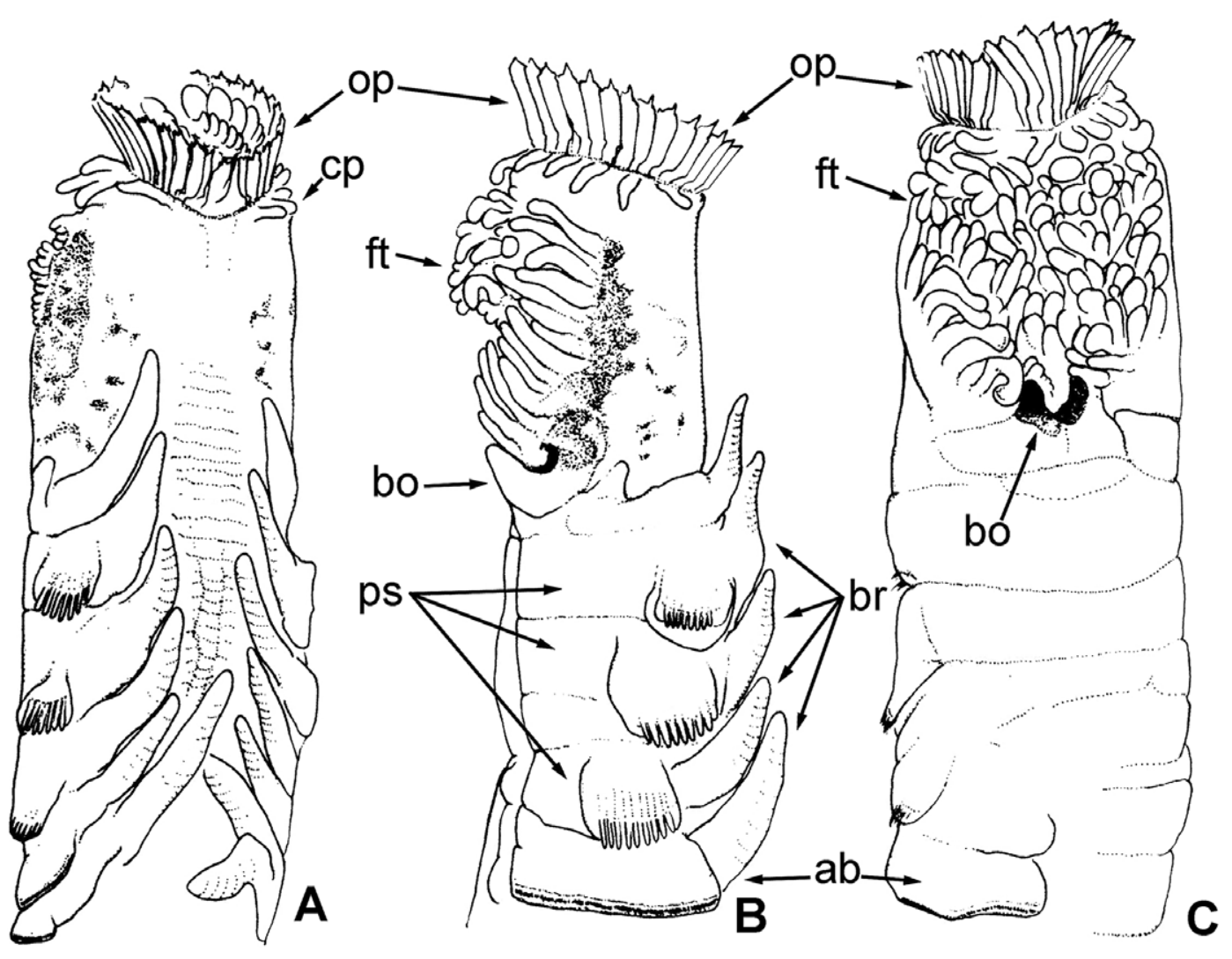

Figure 3. Neosabellaria vitiensis, n. sp., head to anterior abdomen (holotype, врвм R2892). A, Anterior end, dorsal view; $B$, anterior end, lateral (left) view; $C$, anterior end, ventral view. Abbreviations: ab, abdominal chaetiger; bo, building organ; br, branchia; $\mathrm{cp}$, conical papilla; $\mathrm{ft}$, feeding tentacle; op, outer palea; ps, parathoracic chaetiger. Scale $=1.0 \mathrm{~mm}$.

each neuropodia and about 10 chaetae on each of the notopodia (Figure $3 B$ ).

Abdomen with 25 chaetigers in holotype, 10-30 in paratypes, with bundles of $10-15$ long simple capillaries and finely serrated neurochaetae, and elongate conical ventral cirri with uncinigerous tori. Anteriormost 610 abdominal chaetigers with dorsal branchiae, diminishing in size posteriorly (Figure $2 A$ ). Branchiae with horizontal cirral rows (Figure $2 A$ ). Cauda long and bent back on ventrum (Figure $2 A$ ).

Tube constructed of sand and shell debris; sand grains are of black basalt, green olivine, and numerous foraminiferans; inner side coated with thin membrane. Tube length up to $40 \mathrm{~mm}$, tube aperture $1-2 \mathrm{~mm}$ in diameter. Outer diameters of 50 tubes taken from the center of a colony measured about $2 \mathrm{~mm}$, and the inner diameters of the tubes measured about $1.08 \mathrm{~mm}$ (Pohler 2004). Tube mass over $100 \mathrm{~mm}$ in size sometimes leads to colony or "reef" formations (approximately $1-\mathrm{m}$ crusts shown in Figure $1 A, B$ and in Pohler [2004] [Figure $1 C, D]$ ).

Distribution and ecology. The worms form large colonies that develop into massive mounding reefs in nearshore areas. They occur in the intertidal region, within or just below the surf zone, growing on ex- 


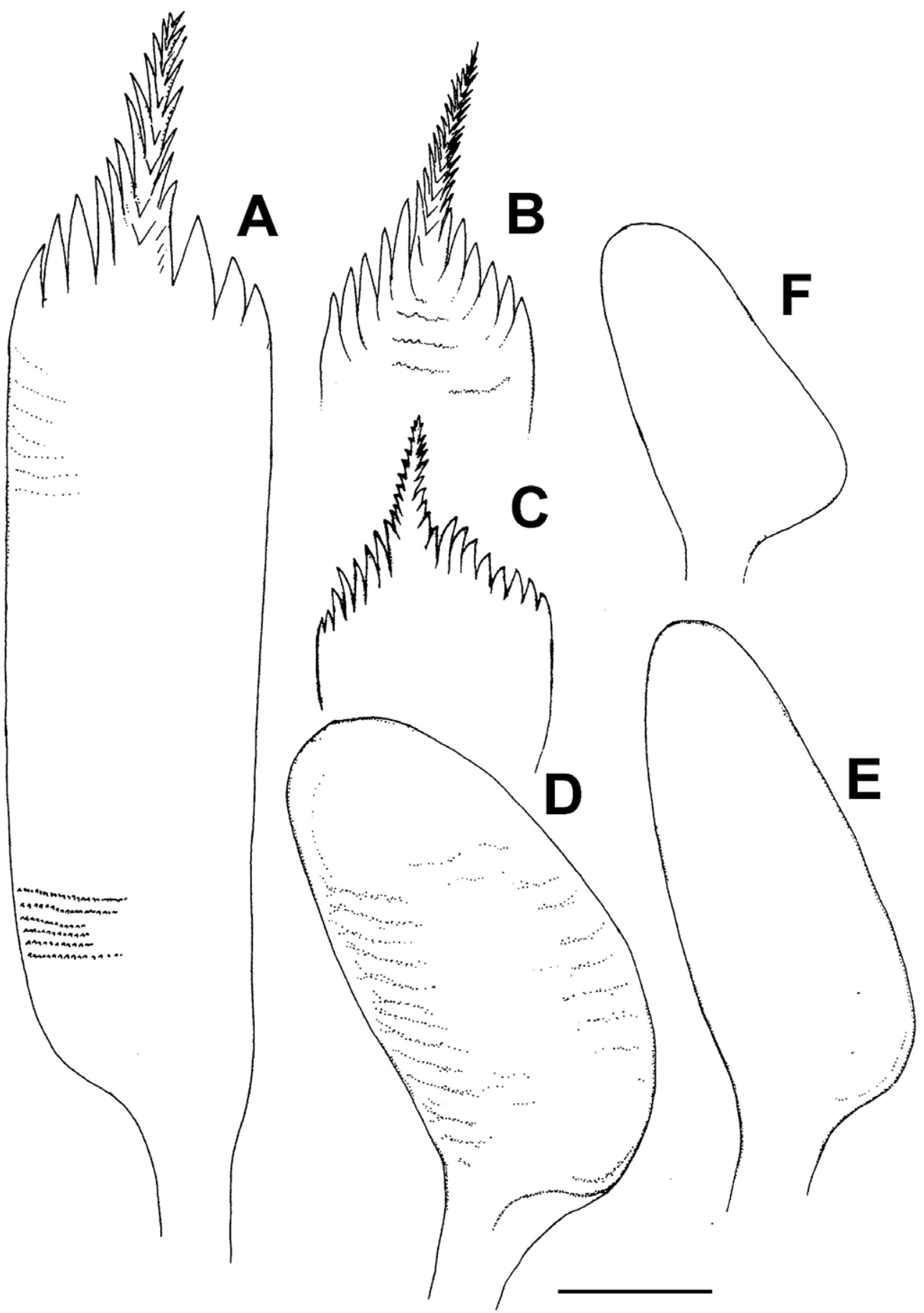

Figure 4. Paleae of Neosabellaria vitiensis, n. sp. (смNн-ZW01662 and 01663). A, outer row palea; $B$, $C$, tip of outer paleae; $D, E$, middle row shoe-shaped paleae; $F$, inner palea. Scale $=0.01 \mathrm{~mm}$. 
posed substrates such as the Suva Marl or riprap rocks, the seawall, and mangrove roots (Bailey-Brock 1985, Pohler 2004) (Figure $1 A-D)$. Sediments are dark muddy sands that receive runoff from the nearby town after seasonal rains. Salinities measured with a refractometer ranged from 26 to $37 \mathrm{ppt}$, temperatures were $27-30^{\circ} \mathrm{C}$ (Pohler 2004). The strong tubes constructed of cemented sand grains and aggregated mounds of tubes are able to resist erosion from wave and storm forces and play a role in reducing sand mobility. Researchers in Fiji are examining ways to enhance the distribution of sabellariids on adjacent reefs, to reduce shoreline erosion (Pohler 2004).

etymology. The species name vitiensis is chosen for the island of the type locality.

\section{DISCUSSION}

Among the Neosabellaria species, only N. clandestina (Menon \& Sareen, 1966) is known to have rounded middle paleae like those of the new species (Menon and Sareen 1966a,b, Day
1973, Kirtley 1994). Outer paleae of N. vitiensis, n. sp. have distal lateral teeth and a denticulate median plume, whereas specimens of $N$. clandestina have outer paleae with asymmetrical distal margins and indistinct protrusions instead of conspicuous dentition. These terminate in a small, medial, frayed, threadlike, spinous distal tip (Kirtley 1994). Menon and Sareen (1966a:438) and Kirtley (1994) noted that type specimens of Neosabellaria clandestina were deposited in the Punjab University, Chandigar, Pakistan, and the Zoologische Museum, University of Hamburg. The type specimens were not available for us to examine. Neosabellaria clandestina (Menon \& Sareen, 1966), described as Sabellaria clandestinus (Menon and Sareen 1966a,b), most closely resembles the new species and is included in the revised key to species of Neosabellaria given here (based on Kirtley 1994:17).

Neosabellaria uschakovi (Kirtley, 1994) differs from the new species from Fiji because it has two kinds of middle opercular paleae; the other five species in the genus do not. Species are distinguished on the structure, length, and curvature of middle paleae (Kirtley 1994).

KEY TO THE SPECIES OF Neosabellaria

1a. Middle opercular paleae of two kinds .............................. uschakovi

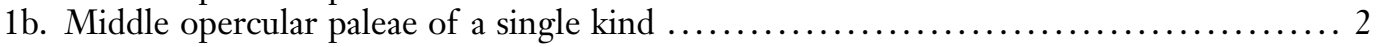

2a. Middle opercular paleae with oval tips..................................... 3

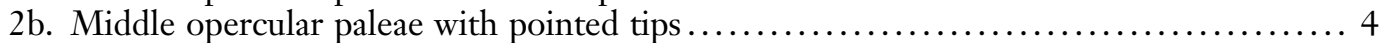

3a. Outer paleae with frayed, small spinous distal tip...................... clandestina

3b. Outer paleae with distal lateral teeth and denticulate median plume....... vitiensis, n. sp.

4a. Middle opercular paleae taper gradually to a point .......................... 5

4b. Middle opercular paleae not tapered gradually to a point $\ldots \ldots \ldots \ldots \ldots \ldots$ N. kaiparaensis

5a. Middle opercular paleae strongly recurved, forming a hooklike distal tip.. N. rupicaproides 5 b. Middle opercular paleae not strongly recurved $\ldots \ldots \ldots \ldots \ldots \ldots \ldots \ldots \ldots \ldots \ldots \ldots$

6. Middle opercular paleae relatively short $\ldots \ldots \ldots \ldots \ldots \ldots \ldots \ldots \ldots \ldots \ldots \ldots \ldots \ldots \ldots \ldots$ antipoda 6b. Middle opercular paleae relatively long............................ cementarium

\section{ACKNOWLEDGMENTS}

We are grateful to Jone Lima for sending materials from Fiji to Japan, and to R. E. Brock for collecting specimens in Fiji and taking photographs of these gregarious sabellariids on the rocks (transportation provided by University of Hawai'i International Sea Grant Program). We also thank two anonymous reviewers for their helpful comments on the 
manuscript. Susan Monden and the late D. Kirtley prepared some of the original illustrations and light micrographs.

\section{Literature Cited}

Bailey-Brock, J. H. 1985. Polychaetes from Fijian coral reefs. Pac. Sci. 39:195-206.

Day, J. H. 1973. Polychaeta collected by U. D. Gaikwad at Ratnagiri, south of Bombay. Zool. J. Linn. Soc. 52:337-361.

Kirtley, D. W. 1992. The sabellariid reefs in the Bay of Mont Saint-Michel, France (edited and translated by B. Caline, Y. Gruet, Legendre, J. Le Rhun, A. L'Homer, R. Mathieu, and R. Zbinden). Fla. Oceanogr. Soc. Contrib. Mar. Sci.1:1-156.

. 1994. A review and taxonomic revi- sion of the family Sabellariidae Johnston, 1865 (Annelida: Polychaeta). Sabecon Press Science Series, Vero Beach, Florida.

Menon, P. K. B., and M. L. Sareen. 1966a. A new species of Sabellariidae (Polychaeta) from India. Zool. Anz. 177:435-438.

- 1966b. Morphology of Sabellaria clandestinus Menon and Sareen (Sabellariidae, Polychaeta). Res. Bull. (n. s.) Punjab Univ., Chandigarh 17 (parts $1 \&$ 2): 131139.

Nishi, E., and T. Kato. 2002. Sabellariidae polychaetes from Japan. Taxa, Proc. Jpn. Soc. Syst. Zool. 13:5-17 (in Japanese).

Pandolfi, J. M., D. R. Robertson, and D. W. Kirtley. 1998. Roles for worms in reefbuilding. Coral Reefs 17:120.

Pohler, S. M. L. 2004. The sabellariid worm colonies of Suva Lagoon, Fiji. South Pac. J. Nat. Hist. 22:36-42. 